\title{
Controversial issues: A mixed study with middle school students
}

\author{
Durdane Öztürk ${ }^{*}$ \\ Social Science Education, Kirsehir Ahi Evran University, Kirsehir, Turkey \\ ORCID: 0000-0001-5116-7933
}

Article history

Received:

01.09.2021

Received in revised form: 08.11.2021

Accepted:

24.11.2021

Key words:

social studies; controversial

issues; mixed method
The purpose of the research was to determine the opinions of middle school students about the inclusion of controversial issues in social studies course. In this mixed methods study, an explanatory design was used, and the participants involved middle school students studying in Kırşehir, Osmaniye, and Diyarbakır provinces of Turkey during the 20202021 academic year. The quantitative data were collected using the "Student Questionnaire for Controversial Issues" while the qualitative data were collected through semi-structured interviews. The quantitative data were analyzed using SPSS 25 and the qualitative data were analyzed through MAXQDA 20. In the analysis of quantitative data, descriptive statistics (percentage, frequency, mean, standard deviation) and t-test and one-way analysis of variance/ANOVA were used since the data had normal distribution. Tukey test was administered to determine between which groups the difference existed. In the qualitative phase, audiorecorded interviews were converted into Word files, then analyzed and divided into meaningful codes. Four themes emerged by combining the codes in common categories. As a result of the research, it was found that the controversial topics that the students wanted to be included in the social studies course the most were human rights and violence. Whilst the subject of terrorism was determined as the subject that the students did not want to be included in the lesson in the quantitative dimension, it was determined that there were different opinions among the students regarding including the subject of terrorism in the qualitative dimension. It was also found that participants' opinions about the inclusion of controversial issues differed in terms of gender, grade level, the city they live in, and reading habits. The reason why all of the students wanted controversial topics to be included in the course was to learn about controversial issues and to raise their awareness of these issues.

\section{Introduction}

In the current globalizing world, many issues related to people are becoming increasingly complex and controversial. According to Berg, Graeffe, and Holdon (2003), the controversial issues, whose definition is also controversial, have the following characteristics in general terms:

\footnotetext{
"Correspondency: durdane.ozturk@ahievran.edu.tr
} 
- It may contain competing values and interests.

- There may be political sensitivity.

- It can arouse various emotions in people.

- It is up-to-date and complex.

Not all controversial issues are the same. Their common point is that they confront individuals with problems whose solutions are open to discussion (Lockwood, 1995). Controversial issues can be defined as issues that people cannot agree about, have more than one solution, are related to various fields, have different value judgments, are local, national, and international, and have individual or social sensitivity. Examples of such issues include human rights, terrorism, global warming, media, violence, the internet, cloning, wars, and alike. The issues selected by teachers to be discussed in classrooms are generally those that are already included in the curriculum or that are related to the objectives of the curriculum (Öztürk \& Kuş, 2019; Hess, 2004).

What is expected from today's citizens is to be sensitive to these issues in the society and world and to be able to produce solutions (Ersoy, 2013). One way to do this is to bring controversial issues into the classroom. Classrooms are good places for controversial issues because they have a large capacity for the diversity of views (Hess, 2004). Although controversial issues tend to arise suddenly during the exchange of ideas in normal classroom functioning, they may sometimes be included in the classroom as part of the lesson and its teaching will stimulate the classroom culture (Miller \& Flores, 2011). In addition, controversial issues require special attention to be included in the classroom environment because they are sensitive from an individual and social point of view (Avaroğulları, 2015). Students also enjoy lessons that include discussions. In addition, there are several benefits of involving students in discussions about controversial issues. Students involved in discussions are more likely to support core democratic values, follow political news in the media, and engage with the political process (Barton \& McCully, 2007). There are multiple reasons for including controversial issues in social studies classes. The three most common of these are to prepare students for the role of citizens in a pluralistic democracy, to develop critical thinking skills, and to develop interpersonal skills (Harwood \& Hahn, 1990). As Yazıcı and Seçgin (2010) stated, supporting students to put forward their ideas by including controversial issues in a social studies course overlaps with the objectives of this course the most because, among the special purposes of the social studies course, there exist individuals' belief in the importance of participation, expressing opinions for the solution of personal and social problems, and demonstrating sensitivity to issues that concern their country and the world (Ministry of National Education, 2018). Controversial issues are given more space in middle schools (Oulton, Dillon \& Grace, 2004). This may be because some of the controversial issues are already in the curriculum. Some of the controversial issues that are covered in the social studies curriculum are freedom of thought, democracy, environmental pollution, technology, economic resources, violence against women, and human rights (MEB, 2018).

It can be expressed that controversial issues are also effective in skill teaching or development. Oxfam (2006) states that the use of controversial issues in the classroom helps students develop many skills, including inquiry, critical thinking, and analytical thinking skills. Before discussing controversial issues in class, it is also important to engage with students and plan how to discuss controversial issues with them (Washington \& Humphries, 2011). Teachers and students need to be prepared before handling the controversial issue. However, it seems that teachers and students have little preparation when a controversial issue arises in the classroom. This situation changes slightly for controversial issues that are 
explicitly present in the curriculum (Chikoko, Harber \& Serf, 2011). Moreover, the teachers who are the implementers of the curriculum are hesitant to discuss controversial issues in the classroom for various reasons (Hess, 2004; Günal \& Kaya, 2016; Öztürk \& Kuş, 2019). However, students are more comfortable engaging in conversations on controversial issues in the classroom (Hess \& Posselt, 2002).

Although there are many studies in the literature with teachers and pre-service teachers on controversial issues in social studies lessons (Ersoy, 2010; Tuncer, 2018; Busey \& Mooney, 2014; Lockwood,1995), the number of studies with students is limited. Revealing the views of the students is important for the teaching of controversial issues in social studies because students constitute one of the pillars of the teaching of controversial issues. Therefore, in this study, it was aimed to reveal the opinions of the students. The problem of this research was "What are the opinions of the students about including controversial issues in social studies lessons?" Based on this problem, the sub-problems were expressed as follows:

(1) Do the students' opinions about controversial issues differ in terms of:

- Gender,

- Reading habit,

- Grade level,

- The city they live in?

(2) What are the students' opinions about the definition of controversial issues?

(3) What are the students' opinions about the lessons including controversial issues?

(4) What are the students' opinions about the controversial issues' being included in the lesson?

(5) What are the students' opinions about the controversial issues' not being included in the lesson?

\section{Methods}

\section{Research model}

A mixed method design was used in the research. In the mixed method, quantitative and qualitative research approaches can be used together to examine the problem in more detail and to obtain more diverse data (Creswell, 2012). In the mixed method, qualitative and quantitative methods can come together in different ways. Accordingly, explanatory design, one of the mixed research designs, was used. The purpose of this two-stage design is to support, explain or exemplify the data collected by quantitative methods using data collected by qualitative methods (Yıldırım \& Şimşek, 2016). In this context, a questionnaire was administered to the participants first, and then their opinions were collected using the semistructured interview technique.

\section{Participants}

The participants in the quantitative phase of the research involved 562 students studying at middle schools in Kırşehir, Osmaniye, and Diyarbakır provinces of Turkey. Of these 562 students, 17 were excluded due to some reasons such as erroneous responses, missing values, and others. Therefore, data obtained from 545 students were analyzed. Stratified sampling technique, one of the random sampling techniques, was used to determine 
the sample. In the qualitative phase in which the purposeful sampling technique was used, a total of 20 students from schools of three different socio-economic statuses in Kurşehir province in Turkey took part in the study. Demographics of participants were illustrated in Table 1 and Table 2.

Table 1. Demographics of participants in quantitative phase

\begin{tabular}{llll}
\hline Variable & & $\mathbf{N}$ & $\mathbf{\%}$ \\
\hline Gender & Female & 289 & 52,7 \\
& Male & 256 & 47,3 \\
\hline \multirow{2}{*}{ Grade Level } & $7^{\text {th }}$ grade & 208 & 38,2 \\
& $6^{\text {th }}$ grade & 171 & 31,4 \\
& $5^{\text {th }}$ grade & 166 & 30,5 \\
\hline City & Osmaniye & 196 & 36,7 \\
& Kirşehir & 178 & 32,7 \\
& Diyarbakır & 171 & 31,4 \\
\hline Reading Habit & Yes & 478 & 87,7 \\
& No & 67 & 12,3 \\
\hline Total & & $\mathbf{5 4 5}$ & $\mathbf{1 0 0}$ \\
\hline
\end{tabular}

Table 1 shows that $52,7 \%(n=289)$ were female while $47,13 \%(n=256)$ were male students. Of the students, 38,2\% $(n=208)$ were 7 graders, 31,4\% $(n=171)$ were 6 graders, and 30,5\% $(\mathrm{n}=166)$ were 5 graders. 36,7\% $(\mathrm{n}=196)$ were from Osmaniye, 32,7\% $(\mathrm{n}=178)$ were from Kırşehir, and 31,4\% $(n=171)$ were from Diyarbakır. 87,7\% $(n=478)$ of students expressed that they read books regularly while $12,3 \%(n=67)$ expressed that they do not.

Table 2. Demographics of participants in the qualitative phase

\begin{tabular}{llll}
\hline Variable & & $\mathbf{N}$ & $\mathbf{\%}$ \\
\hline Gender & Female & 11 & 55 \\
& Male & 9 & 45 \\
\hline Grade Level & $7^{\text {th }}$ grade & 7 & 35 \\
& $6^{\text {th }}$ grade & 6 & 30 \\
& $5^{\text {th }}$ grade & 7 & 35 \\
\hline City & Krrşehir & 20 & 100 \\
\hline Reading Habit & Yes & 17 & 85 \\
& No & 3 & 15 \\
\hline Total & & $\mathbf{2 0}$ & $\mathbf{1 0 0}$ \\
\hline
\end{tabular}

Table 2 demonstrates that $55 \%(n=11)$ of participants were female while $45 \%$ were male students. Of the participants, $35 \%(n=7)$ were 7 graders, $30 \%(n=6)$ were 6 graders, and $35 \%$ $(n=7)$ were 5 graders. All of the participants were studying in Kırşehir $(100 \%, n=20) .85 \%$ $(n=17)$ of participants stated that they read books regularly while $15 \%(n=3)$ expressed that they do not.

\section{Data collection tools}

\section{Quantitative Data Collection Tool}

"Student Questionnaire for Controversial Issues", which was developed by Uygun and Arslan (2020), was used to collect the quantitative data of the study. In the first part of the scale, which consists of two parts, there was personal information about the students, and in the second part, there were 20 controversial issues rated on a 5-point Likert scale. The Alpha reliability coefficient of the scale was 0,74 . In this study, the Cronbach Alpha value was 
checked to determine the reliability. It was 0,78 . A reliability coefficient higher than 0,70 indicated that the questionnaire was reliable (Büyüköztürk, Çakmak, Akgün, Karadeniz, \& Demirel, 2014).

\section{Qualitative Data Collection Tool}

A semi-structured interview form which was developed by the researcher was used to collect the qualitative data of the study. Semi-structured interview form involves questions that were prepared in advance; however, it also allows interviewers to ask additional questions to gather more detailed information about those questions as well (Y1ldirim \& Şimşek, 2016). In this context, a literature review was conducted, 6 questions on controversial issues were prepared and presented to expert opinions. The questions were reviewed based on expert opinions and a pilot test was conducted with 6 students from 5, 6, and 7 grades, which indicated no problem. Face-to-face interviews were conducted with each student, which lasted approximately 15-20 minutes. The following questions were adressed in the semi-structured interview form:

(1) What is a controversial issue in your opinion?

(2) In which courses the controversial issues are covered?

(3) Which controversial issues should be included in the social studies course? Why?

(4) Which controversial issues should not be included in the social studies course? Why?

The research was approved by Kırşehir Ahi Evran University Social Sciences and Humanities Research and Publication Ethics Committee dated 27.05.2021 and numbered 2021/3/11.

\section{Data analysis}

\section{Quantitative data analysis}

The quantitative data were analyzed using SPSS 25 software. In the analysis of quantitative data, descriptive statistics (percentage, frequency, mean, standard deviation) and t-test and one-way analysis of variance/ANOVA were used since the data had normal distribution. Tukey test, one of the post hoc tests, was administered to determine between which groups the difference was. The normal distribution of the data was checked examining skewness and kurtosis values. The skewness values ranged from -1.620 to .483 while the kurtosis values varied between -1.518 and 1.769. The skewness and kurtosis values between +2 and -2 indicate the normal distribution of the data (George \& Mallery, 2010). The 5 categories created to determine the opinions of the students on controversial issues can be seen in Table 3.

Table 3. Ranges of the scale

\begin{tabular}{lll}
\hline Weight & Variants & Range \\
\hline 5 & Strongly Agree & $4.20-5.00$ \\
4 & Agree & $3.40-4.19$ \\
3 & Neutral & $2.60-3.39$ \\
2 & Disagree & $1.80-2.59$ \\
1 & Strongly Disagree & $1-1.79$ \\
\hline
\end{tabular}

\section{Qualitative data analysis}

With the consent of the participants, the qualitative data obtained with the voice recorder were converted into text using the Microsoft Word software. These texts were 
analyzed using the MAXQDA 2020 qualitative data analysis software. The main purpose of content analysis is to reach concepts and relationships that can explain the collected data (Y1ldırım \& Şimşek, 2016). The texts were coded separately by two different researchers. The reliability was calculated $90 \%$ using the intercoder agreement correlation formula [Agreement/ (Agreement + Disagreement) x100] (Miles \& Huberman, 1994). In this context, the interviews were analyzed in detail and divided into meaningful codes. Four themes were reached by combining the codes in common categories.

\section{Results}

\section{Opinions about including controversial issues}

The percentage (\%) and frequencies (f) of students' opinions about including controversial issues are illustrated in Table 4.

Table 4. Percentages and frequencies of students' opinions about controversial issues

\begin{tabular}{|c|c|c|c|c|c|c|c|c|c|c|c|c|}
\hline \multirow[t]{2}{*}{ Items } & \multicolumn{2}{|c|}{ 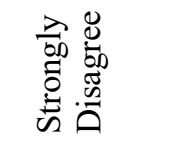 } & \multicolumn{2}{|l|}{ 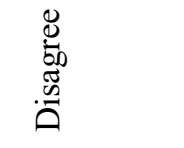 } & \multicolumn{2}{|c|}{$\begin{array}{l}\underset{\pi}{0} \\
\stackrel{0}{0} \\
Z\end{array}$} & \multicolumn{2}{|c|}{ 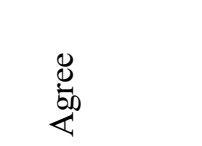 } & \multicolumn{2}{|c|}{ 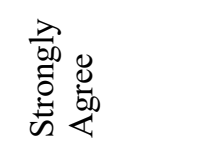 } & \multirow[b]{2}{*}{$\overline{\mathrm{X}}$} & \multirow[b]{2}{*}{ Ss } \\
\hline & $\mathrm{f}$ & $\%$ & $\mathrm{f}$ & $\%$ & $\mathrm{f}$ & $\%$ & $\mathrm{f}$ & $\%$ & $\mathrm{f}$ & $\%$ & & \\
\hline Military Service & 65 & 11.9 & 71 & 13.0 & 134 & 24.6 & 111 & 20.4 & 164 & 30.1 & 3.43 & 1.35 \\
\hline $\begin{array}{l}\text { Freedom of the } \\
\text { Press }\end{array}$ & 35 & 6.4 & 54 & 9.9 & 154 & 28.3 & 147 & 27.0 & 155 & 28.4 & 3.61 & 1.18 \\
\hline $\begin{array}{l}\text { Religious } \\
\text { Congregations }\end{array}$ & 68 & 12.5 & 77 & 14.1 & 148 & 27.2 & 99 & 18.2 & 153 & 28.1 & 3.35 & 1.35 \\
\hline Multiculturalism & 20 & 3.7 & 47 & 8.6 & 99 & 18.2 & 142 & 26.1 & 237 & 43.5 & 3.97 & 1.13 \\
\hline Fanaticism & 67 & 12.3 & 110 & 20.2 & 151 & 27.7 & 119 & 21.8 & 98 & 18.0 & 3.13 & 1.27 \\
\hline $\begin{array}{l}\text { Inequality in } \\
\text { Income } \\
\text { Distribution }\end{array}$ & 82 & 15.0 & 76 & 13.9 & 134 & 24.6 & 92 & 16.9 & 161 & 29.5 & 3.31 & 1.41 \\
\hline Migration & 69 & 12.7 & 108 & 19.8 & 149 & 27.3 & 109 & 20.0 & 110 & 20.2 & 3.15 & 1.30 \\
\hline Animal Rights & 29 & 5.3 & 30 & 5.5 & 62 & 11.4 & 122 & 22.4 & 302 & 55.5 & 4.17 & 1.15 \\
\hline Human Rights & 26 & 4.8 & 22 & 4.0 & 57 & 10.5 & 100 & 18.3 & 340 & 62.4 & 4.29 & 1.11 \\
\hline Internet & 27 & 5.0 & 47 & 8.6 & 106 & 19.4 & 147 & 27.0 & 218 & 40.0 & 3.88 & 1.17 \\
\hline Cloning & 94 & 17.2 & 82 & 15.0 & 203 & 37.2 & 58 & 10.6 & 108 & 19.8 & 3.00 & 1.32 \\
\hline Substance Abuse & 192 & 35.2 & 69 & 12.7 & 86 & 15.8 & 82 & 15.0 & 116 & 21.3 & 2.74 & 1.57 \\
\hline Media & 50 & 9.2 & 70 & 12.8 & 146 & 26.8 & 146 & 26.8 & 133 & 24.4 & 3.44 & 1.24 \\
\hline $\begin{array}{l}\text { Nuclear Power } \\
\text { Plants }\end{array}$ & 86 & 15.8 & 90 & 16.5 & 160 & 29.4 & 94 & 17.2 & 115 & 21.1 & 3.11 & 1.34 \\
\hline Privatization & 53 & 9.7 & 69 & 12.7 & 177 & 32.5 & 115 & 21.1 & 131 & 24.0 & 3.37 & 1.24 \\
\hline Election System & 52 & 9.5 & 52 & 9.5 & 135 & 24.8 & 127 & 23.3 & 179 & 32.8 & 3.60 & 1.28 \\
\hline Violence & 199 & 36.5 & 76 & 13.9 & 83 & 15.2 & 47 & 8.6 & 140 & 25.7 & 2.73 & 1.62 \\
\hline Terrorism & 205 & 37.6 & 101 & 18.5 & 83 & 15.2 & 72 & 13.2 & 84 & 15.4 & 2.50 & 1.48 \\
\hline Traffic & 67 & 12.3 & 61 & 11.2 & 109 & 20.0 & 122 & 22.4 & 186 & 34.1 & 3.54 & 1.37 \\
\hline TV Broadcasts & 59 & 10.8 & 58 & 10.6 & 123 & 22.6 & 143 & 26.2 & 162 & 29.7 & 3.53 & 1.30 \\
\hline
\end{tabular}

As can be seen in Table 4, when the students' opinions about the inclusion of controversial issues in social studies course were examined, it was observed that they expressed Human Rights $(\overline{\mathrm{X}}=4.29)$ at the "Strongly Agree" level.

The issues that the students expressed at the "Agree" level were Animal Rights $(\overline{\mathrm{X}}=4.17)$, Multiculturalism $(\overline{\mathrm{X}}=3.97)$ Internet $(\overline{\mathrm{X}}=3.88)$, Freedom of the Press $(\overline{\mathrm{X}}=3.61)$, Election System $(\overline{\mathrm{X}}=3.60)$, Traffic $(\overline{\mathrm{X}}=3.54)$, Tv Broadcasts $(\overline{\mathrm{X}}=3.53)$, Media $(\overline{\mathrm{X}}=3.44)$, and Military 
Service $(\overline{\mathrm{X}}=3.43)$, respectively.

The issues that the students expressed at the "Neutral" level were Privatization $(\overline{\mathrm{X}}=3.37)$, Religious Congregations $(\overline{\mathrm{X}}=3.35)$, Inequality in Income Distribution $(\overline{\mathrm{X}}=3.31)$, Migration $(\overline{\mathrm{X}}=3.15)$, Fanaticism $(\overline{\mathrm{X}}=3.13)$, Nuclear Power Plants $(\overline{\mathrm{X}}=3.11)$, Cloning $(\overline{\mathrm{X}}=3.00)$, Substance Abuse $(\overline{\mathrm{X}}=2.74)$, and Violence $(\overline{\mathrm{X}}=2.73)$. The students expressed Terrorism $(\overline{\mathrm{X}}=2.50)$ at the "Disagree" level. They did not express any opinion at the "Strongly Disagree" level.

\section{Opinions about including controversial issues in terms of gender}

Independent samples t-test was conducted to determine whether students' opinions about including controversial issues differed in terms of gender. The results can be seen in Table 5.

Table 5. T-test results regarding gender variable

\begin{tabular}{|c|c|c|c|c|c|c|c|}
\hline Items & Group & $\mathbf{N}$ & $\overline{\mathbf{X}}$ & Sd & df & $\mathbf{t}$ & $\mathbf{p}$ \\
\hline Military Service & Female & 289 & 3.05 & 1.36 & \multirow{4}{*}{543} & -7.255 & .000 \\
\hline & Male & 256 & 3.86 & 1.20 & & & \\
\hline \multirow[t]{2}{*}{ Fanaticism } & Female & 289 & 3.00 & 1.23 & & -2.417 & .016 \\
\hline & Male & 256 & 3.26 & 1.30 & & & \\
\hline
\end{tabular}

The examination of Table 5 shows that male students' mean of Military Service was $(\overline{\mathrm{X}}=3.86)$ while the mean of female students was $(\bar{X}=3.05)$. Male students had significantly higher scores in their opinions about controversial issues in terms of Military Service $[\mathrm{t}(543)=-7.255$; $\mathrm{p}<0.05]$. In terms of fanaticism, the mean score of female students was $(\bar{X}=3.00)$ whilst the mean score of male students was $(\overline{\mathrm{X}}=3.26)$. Male students had significantly higher scores from fanaticism item $[\mathrm{t}(543)=-2.417 ; \mathrm{p}<0.05]$.

\section{Opinions about including controversial issues in terms of reading habits}

Independent samples t-test was conducted to determine whether students' opinions about including controversial issues differed in terms of reading habits. The results can be seen in Table 6.

Table 6. T-test results regarding reading habit variable

\begin{tabular}{|c|c|c|c|c|c|c|c|}
\hline & Group & $\mathbf{N}$ & $\overline{\mathbf{X}}$ & Sd & df & $\mathbf{t}$ & $\mathbf{p}$ \\
\hline \multirow[t]{2}{*}{ Multiculturalism } & Yes & 478 & 4.03 & 1.09 & & 3.59 & .000 \\
\hline & No & 67 & 3.50 & 1.30 & & & \\
\hline \multirow[t]{2}{*}{ Animal Rights } & Yes & 478 & 4.23 & 1.10 & & 3.58 & .000 \\
\hline & No & 67 & 3.70 & 1.38 & & & \\
\hline \multirow{2}{*}{ Human Rights } & Yes & 478 & 4.35 & 1.07 & & 3.17 & .002 \\
\hline & No & 67 & 3.89 & 1.29 & $67 / 478$ & & \\
\hline \multirow[t]{2}{*}{ Privatization } & Yes & 478 & 3.41 & 1.22 & 545 & 2.40 & .017 \\
\hline & No & 67 & 3.02 & 1.35 & & & \\
\hline \multirow[t]{2}{*}{ Election System } & Yes & 478 & 3.67 & 1.27 & & 3.52 & .000 \\
\hline & No & 67 & 3.08 & 1.26 & & & \\
\hline
\end{tabular}

Examination of Table 6 shows that the scores obtained from multiculturalism, animal rights, human rights, privatization, and election system significantly differed in terms of reading habit. In terms of multiculturalism, the mean score of students who had reading habits was $(\overline{\mathrm{X}}=4.03)$ while the mean score of students who did not have reading habits was $(\overline{\mathrm{X}}=3.50)$. Students who had reading habits had significantly higher scores from the multiculturalism 
item $\left[\mathrm{t}_{(545)}=3.59 ; \mathrm{p}<0.05\right]$. In terms of animal rights, the mean score of students who had reading habits was $(\overline{\mathrm{X}}=4.23)$ while the mean score of students who did not have reading habits was $(\overline{\mathrm{X}}=3.70)$. Students who had reading habits had significantly higher scores from the animal rights item $[\mathrm{t}(545)=3.58 ; \mathrm{p}<0.05]$. In terms of human rights, the mean score of students who had reading habits was $(\overline{\mathrm{X}}=4.35)$ while the mean score of students who did not have reading habits was $(\overline{\mathrm{X}}=3.89)$. Students who had reading habits had significantly higher scores from the human rights item $\left[\mathrm{t}_{(545)}=3.17 ; \mathrm{p}<0.05\right]$. In terms of privatization, the mean score of students who had reading habits was $(\bar{x}=3.41$ while the mean score of students who did not have reading habits was $(\overline{\mathrm{X}}=3.02)$. Students who had reading habits had significantly higher scores from the privatization item $\left[\mathrm{t}_{(545)}=2.40 ; \mathrm{p}<0.05\right]$. In terms of the election system, the mean score of students who had reading habits was $(\bar{X}=3.67)$ while the mean score of students who did not have reading habits was $(\overline{\mathrm{X}}=3.08)$. Students who had reading habits had significantly higher scores from the election system item $\left[\mathrm{t}_{(545)}=3.52 ; \mathrm{p}<0.05\right]$.

\section{Opinions about including controversial issues in terms of grade levels}

One-way analysis of variance was conducted to determine whether students' opinions about including controversial issues differed in terms of grade levels. The results can be seen in Table 7.

Table 7. ANOVA results regarding grade level variable

\begin{tabular}{|c|c|c|c|c|c|c|c|c|}
\hline Items & Group & $\mathrm{N}$ & $\overline{\mathrm{X}}$ & $\mathrm{Sd}$ & $\mathrm{df}$ & $\mathrm{F}$ & $\mathrm{p}$ & $\begin{array}{l}\text { Significant } \\
\text { difference }\end{array}$ \\
\hline & 5 th & 166 & 3.59 & 1.26 & $2 / 542$ & 3.87 & .021 & $7-6$ \\
\hline \multirow[t]{4}{*}{ Freedom of the Press } & 6th & 171 & 3.43 & 1.12 & & & & \\
\hline & 7 th & 208 & 3.76 & 1.14 & & & & \\
\hline & Total & 544 & 3.61 & 1.80 & 544 & & & \\
\hline & 5 th & 166 & 3.60 & 1.36 & $2 / 542$ & 5.54 & .004 & $5-7$ \\
\hline Religious & 6th & 171 & 3.35 & 1.27 & & & & \\
\hline \multirow{2}{*}{ Congregations } & 7 th & 208 & 3.14 & 1.37 & & & & \\
\hline & Total & 544 & 3.35 & 1.35 & 544 & & & \\
\hline \multirow{4}{*}{ Multiculturalism } & 5 th & 166 & 4.14 & 1.06 & $2 / 542$ & 6.64 & .001 & $5-7$ \\
\hline & 6th & 171 & 4.07 & 1.10 & & & & $6-7$ \\
\hline & 7 th & 208 & 3.75 & 1.18 & & & & \\
\hline & Total & 544 & 3.35 & 1.35 & 544 & & & \\
\hline \multirow{4}{*}{ Fanaticism } & 5 th & 166 & 3.09 & 1.28 & $2 / 542$ & 6.65 & .001 & $6-7$ \\
\hline & 6th & 171 & 3.40 & 1.24 & & & & \\
\hline & 7 th & 208 & 2.93 & 1.25 & & & & \\
\hline & Total & 544 & 3.13 & 1.27 & 544 & & & \\
\hline \multirow{4}{*}{ Animal Rights } & 5 th & 166 & 4.34 & 1.07 & $2 / 542$ & 3.46 & .032 & $5-7$ \\
\hline & 6th & 171 & 4.16 & 1.10 & & & & \\
\hline & 7 th & 208 & 4.03 & 1.24 & & & & \\
\hline & Total & 544 & 4.17 & 1.15 & 544 & & & \\
\hline \multirow{4}{*}{ Privatization } & 5 th & 166 & 3.54 & 1.29 & $2 / 542$ & 5.37 & .005 & $5-7$ \\
\hline & 6th & 171 & 3.46 & 1.24 & & & & \\
\hline & 7 th & 208 & 3.15 & 1.17 & & & & \\
\hline & Total & 544 & 3.37 & 1.24 & 544 & & & \\
\hline \multirow{4}{*}{ Terrorism } & 5 th & 166 & 2.40 & 1.49 & $2 / 542$ & 3.13 & .045 & $7-6$ \\
\hline & 6th & 171 & 2.35 & 1.42 & & & & \\
\hline & 7 th & 208 & 2.70 & 1.49 & & & & \\
\hline & Total & 544 & 2.50 & 1.48 & 544 & & & \\
\hline
\end{tabular}

Examination of Table 7 shows that the scores obtained from freedom of the press, religious congregations, multiculturalism, fanaticism, animal rights, privatization, and terrorism 
significantly differed in terms of grade level $\left[\mathrm{F}_{(2-542)}=3.87,5.54,6.64,6.65,3.46,5.37,3.13\right.$; $\mathrm{p}<0.05]$. In terms of freedom of the press, the significant difference was between 6 and 7 graders in favor of 7 graders; in terms of religious congregations, the significant difference was between 5 and 7 graders in favor of 5 graders; in terms of multiculturalism, the significant difference was between 5 and 7 graders in favor of 5 graders and was between 6 and 7 graders in favor of 6 graders; in terms of fanaticism, the significant difference was between 6 and 7 graders in favor of 6 graders; in terms of animal rights, the significant difference was between 5 and 7 graders in favor of 5 graders; in terms of privatization, the significant difference was between 5 and 7 graders in favor of 5 graders; and in terms of terrorism, the significant difference was between 7 and 6 graders in favor of 7 graders.

\section{Opinions about including controversial issues in terms of the city they live in}

One-way analysis of variance was conducted to determine whether students' opinions about including controversial issues differed in terms of the city they live in. The results can be seen in Table 8.

Table 8. ANOVA results regarding the city variable

\begin{tabular}{|c|c|c|c|c|c|c|c|c|}
\hline & Group & $\mathrm{N}$ & $\overline{\mathrm{X}}$ & $\mathrm{Sd}$ & $\mathrm{df}$ & $\mathrm{F}$ & $\mathrm{p}$ & $\begin{array}{l}\text { Significant } \\
\text { difference }\end{array}$ \\
\hline \multirow{4}{*}{ Multiculturalism } & Kırşehir & 178 & 4.18 & 1.05 & & \multirow[t]{4}{*}{5.427} & \multirow[t]{4}{*}{.005} & Kurşehir- \\
\hline & Osmaniye & 196 & 3.92 & 1.17 & $2 / 542$ & & & Diyarbakır \\
\hline & Diyarbakır & 171 & 3.79 & 1.14 & & & & \\
\hline & Total & 545 & 3.97 & 1.37 & & & & \\
\hline \multirow{4}{*}{ Animal Rights } & Kırşehir & 178 & 4.33 & 1.09 & & \multirow[t]{4}{*}{5.215} & \multirow[t]{4}{*}{.006} & Kırşehir- \\
\hline & Osmaniye & 196 & 3.96 & 1.32 & $2 / 542$ & & & Osmaniye \\
\hline & Diyarbakır & 171 & 4.23 & .96 & & & & \\
\hline & Total & 545 & 4.17 & 1.15 & & & & \\
\hline \multirow{4}{*}{ Substance Abuse } & Kırşehir & 178 & 3.06 & 1.60 & & \multirow[t]{4}{*}{6.546} & \multirow[t]{4}{*}{.002} & Kırşehir- \\
\hline & Osmaniye & 196 & 2.47 & 1.57 & $2 / 542$ & & & Osmaniye \\
\hline & Diyarbakır & 171 & 2.71 & 1.48 & & & & \\
\hline & Total & 545 & 2.74 & 1.57 & & & & \\
\hline Nuclear & Kırşehir & 178 & 3.20 & 1.29 & & \multirow[t]{4}{*}{3.669} & \multirow[t]{4}{*}{.026} & Diyarbakır- \\
\hline \multirow[t]{3}{*}{ Plants } & Osmaniye & 196 & 2.90 & 1.41 & $2 / 542$ & & & Osmaniye \\
\hline & Diyarbakır & 171 & 3.25 & 1.29 & & & & \\
\hline & Total & 545 & 3.11 & 1.34 & & & & \\
\hline \multirow[t]{4}{*}{ Violence } & Kırşehir & 178 & 2.98 & 1.61 & & \multirow[t]{4}{*}{4.647} & \multirow[t]{4}{*}{.010} & Kırşehir- \\
\hline & Osmaniye & 196 & 2.47 & 1.58 & $2 / 542$ & & & Osmaniye \\
\hline & Diyarbakır & 171 & 2.74 & 1.65 & & & & \\
\hline & Total & 545 & 2.73 & 1.62 & & & & \\
\hline \multirow[t]{4}{*}{ Terrorism } & Kırşehir & 178 & 2.76 & 1.58 & & \multirow[t]{4}{*}{5.370} & \multirow[t]{4}{*}{.005} & Kırşehir- \\
\hline & Osmaniye & 196 & 2.26 & 1.43 & $2 / 542$ & & & Osmaniye \\
\hline & Diyarbakır & 171 & 2.50 & 1.38 & & & & \\
\hline & Total & 545 & 2.50 & 1.48 & & & & \\
\hline
\end{tabular}

Examination of Table 8 shows that the scores obtained from multiculturalism, animal rights, substance abuse, nuclear power plants, violence, and terrorism significantly differed in terms of the city they live in $[\mathrm{F}(2-542)=5.427,5.215,6.546,3.669,4.647,5.370 ; \mathrm{p}<0.05]$. In terms of multiculturalism, the significant difference was between the students living in Kurşehir and Diyarbakır in favor of those living in Kırşehir; in terms of animal rights, the significant difference was between the students living in Kırşehir and Osmaniye in favor of those living in Kırşehir; in terms of substance abuse, the significant difference was between the students living in Kırşehir and Osmaniye in favor of those living in Kırşehir; in terms of nuclear power plants, the significant difference was between the students living in Diyarbakir and Osmaniye 
in favor of those living in Diyarbakır; in terms of violence, the significant difference was between the students living in Kırşehir and Osmaniye in favor of those living in Kırşehir; and in terms of terrorism, the significant difference was between the students living in Kurşehir and Osmaniye in favor of those living in Kırşehir.

\section{Findings regarding the qualitative data}

As a result of the analysis of the data obtained from the answers given by the students to the questions about the controversial issues, the findings were presented in four themes using direct quotations. These themes were illustrated in Figure 1.

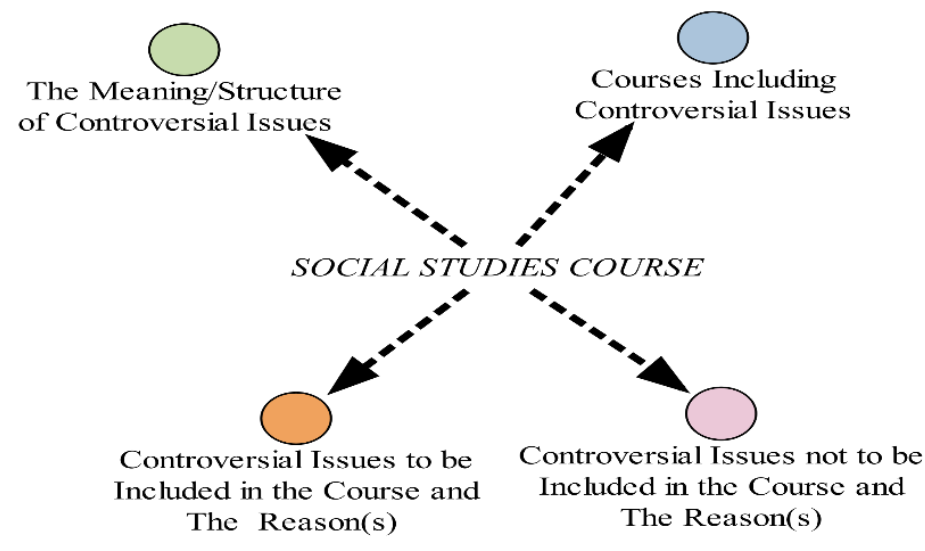

Figure 1. The hierarchical code-subcode model of themes

\section{The meaning/structure of controversial issues}

The participants were first asked, "What is a controversial issue in your opinion?" With this question, it was tried to understand how the students perceived the controversial issue. The findings were demonstrated in Figure 2 under the theme of the meaning/structure of the controversial issue.

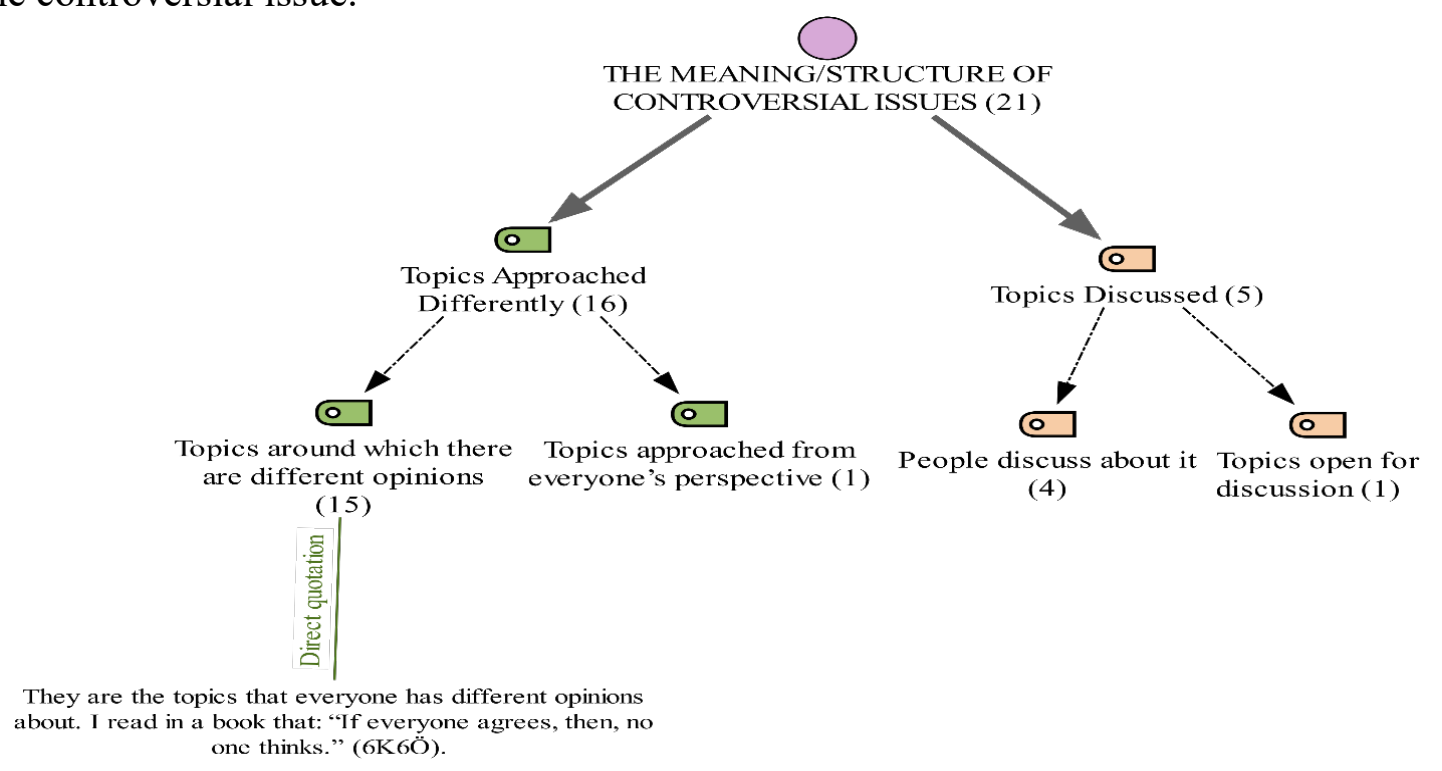

Figure 2. The hierarchical code-subcode model of the meaning/structure of controversial issues 
As can be seen in Figure 2, the meaning/structure of the controversial issues theme was composed of two categories. These were topics approached differently and topics discussed.

In the category of topics approached differently, the participants stated that the controversial issue is a topic on which people have different ideas or thoughts making individuals think about the same issue through different perspectives. The student coded 7E2Ö expressed controversial issues are the topics approached differently as: "Most people have varying opinions on the controversial issue. In other words, if there are a lot of opinions on a topic, that topic is controversial."

In the category of topics discussed, the participants stated that controversial issues are the topics that people discuss or the topics that are suitable for discussion. The student coded 6K4Ö expressed that these topics are controversial issues as: "Recently, people have been talking and discussing issues such as Covid-19, the measures taken regarding the virus, and the depletion of water. Controversial issues like this are the ones people discuss."

\section{Courses including controversial issues}

The participants were asked "In which courses the controversial issues are covered?" to determine their opinions about the courses covering controversial issues. The findings were demonstrated in Graph 1 under the theme of courses including controversial issues.

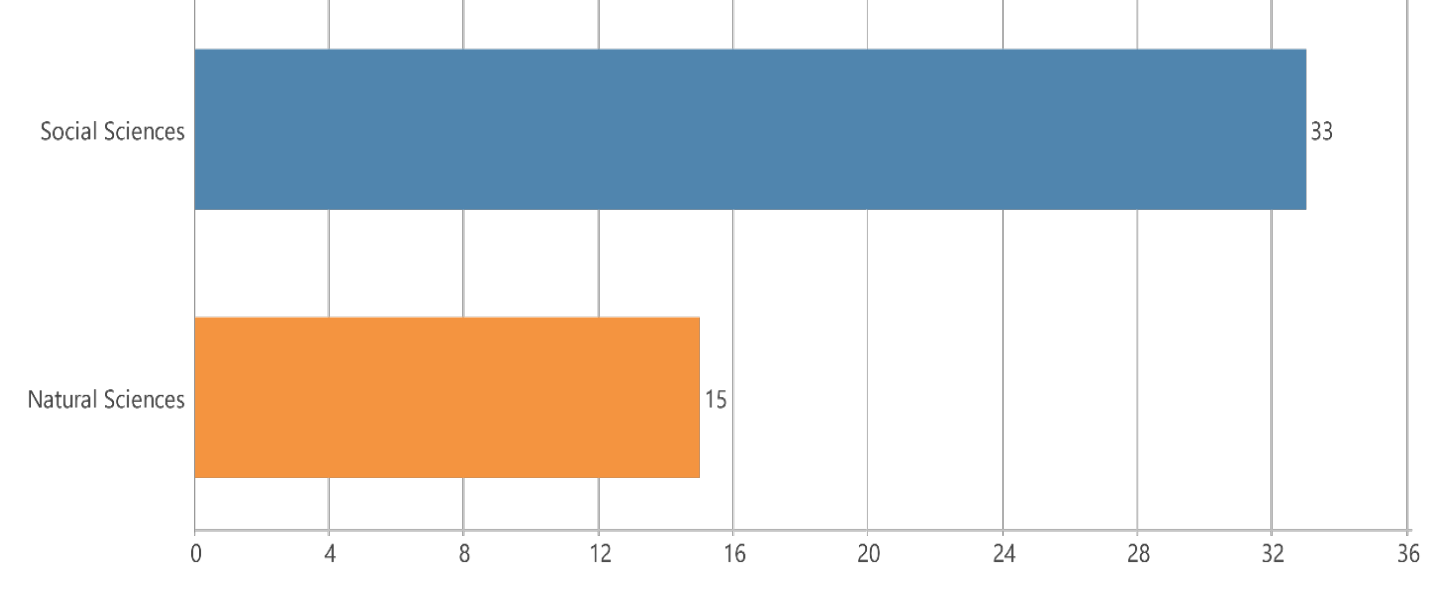

Graph 1. The statistics of subcodes of courses including controversial issues theme

As can be seen in Graph 1, the theme of courses including controversial issues was composed of two categories. These were social sciences and natural sciences.

In the social sciences category, the participants expressed those controversial issues were covered in social studies (f:19), Turkish (f:10), religious culture and morals (f:3), psychological counseling and guidance (f:1). According to the findings, it was observed that controversial issues are mostly included in the social studies course. The student coded 6E3Ö stated that controversial issues were mostly covered in social studies as: "It is covered more in the social studies course because the content of the social studies course is very suitable for these subjects. Some controversial topics can even be the subject of our course. We also study social life in the social studies class. Controversial issues are also covered more in this course because they are included in social life."

In the natural sciences category, the participants indicated that controversial issues were 
covered in science (f:13) and math (f:3). According to the findings, it was observed that science was the course in which the most controversial topics were covered after the social studies course. The student coded 5E7Ö expressed those controversial issues are covered in a science course as: "I think controversial issues, which concern people and pose a problem, entail seeking solutions through science, so controversial issues are included in the science course. For example, the problem of global warming, depletion of water resources."

\section{Controversial issues to be included in the course and its reasons}

The participants were asked "Which controversial issues should be included in the social studies course? Why?" to determine their opinions about which issues they want to be covered in courses and their reasons. The findings were illustrated in Figure 3 under the theme of controversial issues to be included in the course and its reasons.

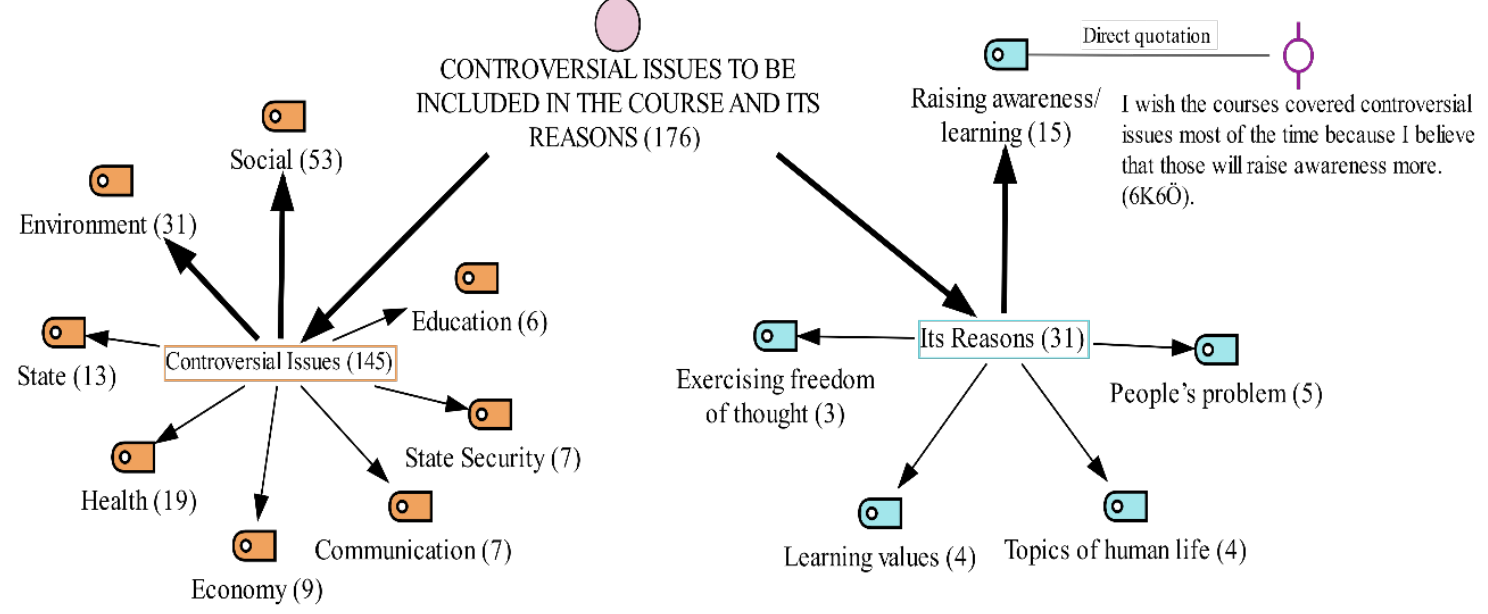

Figure 3. The hierarchical code-subcode model of the controversial issues to be included in the course and its reasons

As can be seen in Figure 3, the theme of controversial issues to be included in the course and its reasons was composed of two categories. These are controversial issues and their reasons.

In the category of controversial issues, the participants expressed that they want topics about social (violence (f:21), rights (f:14)) most and environment (global warming (f:12), environment pollution (f:11)) to be covered in social studies course. Moreover, they wanted topics about health (Covid-19(f:8), measures taken against the pandemic (f:8), vaccine (f:3)) as well as the state (relations with neighbors (f:9), administration (f:3)) to be covered in social studies course. Additionally, they wanted other topics such as the economy (euro rate increase (f:6), the effects of the pandemic on economy (f:2)), communication (media (f:3), Tv broadcasts (f:3)), state security (terrorism (f:4), military service (f:3)), and education (distant education (f:3), equality of opportunity in education (f:3)) to be covered.

The student coded 7E6Ö expressed his opinions about violence, which is among the controversial issues in the social area, as: "I mean violence in general. I am not talking about violence against women, but against children, men, and animals. This has been witnessed a lot lately. What can be done to prevent this situation, what measures can be taken? These should be addressed so that it can be prevented." while 7K5Ö stated her opinions about terrorism, which is among the controversial issues in state security, as: "I think the issue of terrorism should also be included. Not in a very detailed fashion, but it should be mentioned superficially so that children stay away from it." 
In the category of its reasons, the participants expressed that they want controversial issues to be included in social studies course to develop awareness and learn about them (f:15). Moreover, they stated that controversial issues should be included because they are people's problems (f:5) and they are already a part of human life (f:4). They also expressed that these issues provide the chance to exercise the freedom of thought (f:3) and learn some values (f:4).

The student coded 6K5Ö expressed her opinions about learning controversial issues and developing awareness as: "Controversial issues can somehow enter our lives. For example, Covid-19 suddenly entered our lives and has become a part of our lives now. We need to learn many controversial issues like this for our daily life. It is not just about the lesson."

\section{Controversial issues not to be included in the course and its reasons}

The participants were asked "Which controversial issues should not be included in the social studies course? Why?" to determine their opinions about which issues they do not want to be covered in courses and their reasons. The findings were illustrated in Figure 4 under the theme of controversial issues not to be included in the course and its reasons.

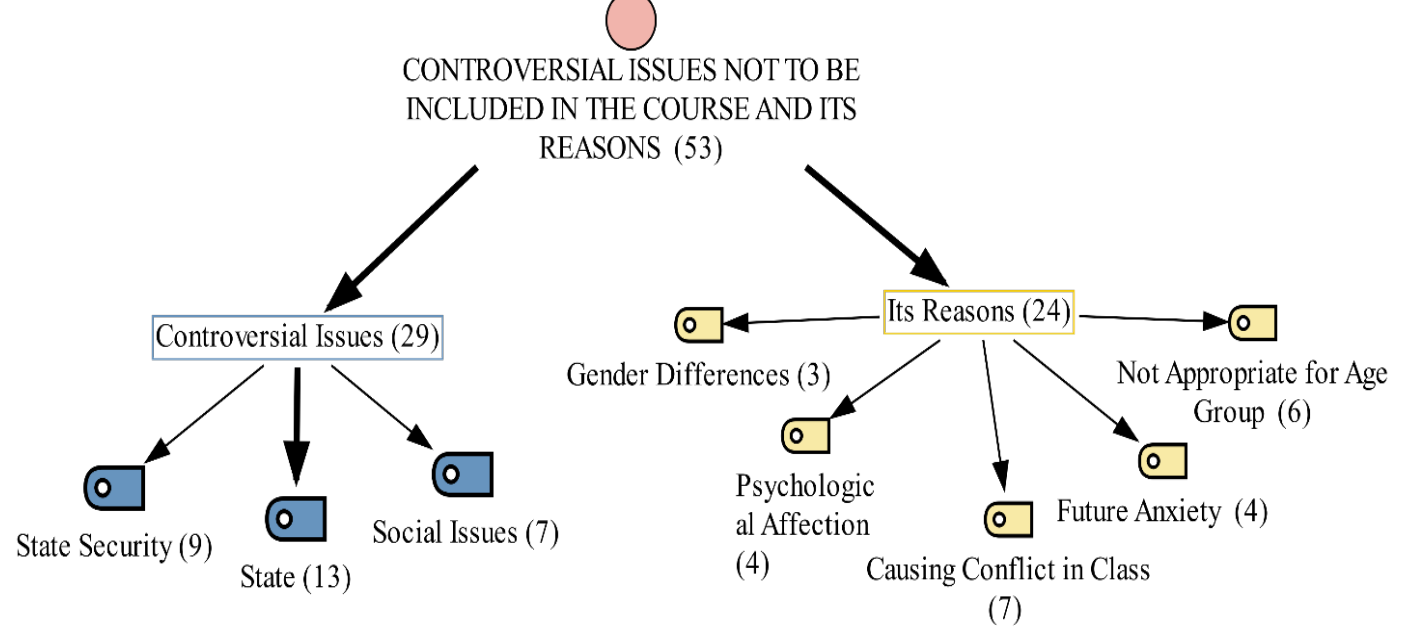

Figure 4. The hierarchical code-subcode model of the controversial issues not to be included in the course and its reasons

As can be seen in Figure 4, the theme of controversial issues not to be included in the course and its reasons was composed of two categories. These are controversial issues and its reasons. In the category of controversial issues, the participants expressed that they do not want topics about the state (politics (f:5), political parties (f:5), government (f:3)) most, and then, the state security (military service (f:6), terrorism (f:3)) to be covered in social studies course. The participants also expressed that they do not want some controversial issues in the social field (child abuse (f:4), violence against children (f:3)) to be covered.

The student coded 6K5Ö expressed her opinions about not including controversial issues about the state as: "It is often not possible to discuss political parties or talk about the government in the classroom. What is said during the speech is conveyed to our families and even to the school administration later on." while the student coded 7K4Ö stated her opinions about state security as: "In my opinion, there is no need to include topics such as the military system and the army. These topics can be included and discussed in television broadcasts, meetings, discussion programs, but there is no point in including them in the course." 
In the category of its reasons, the participants expressed that they do not want controversial issues to be included in social studies course because they cause conflict in the classroom (f:7), they are not appropriate to students' age (f:6), they affect students psychologically (f:4), some students are not able to talk freely due to future anxiety (f:4), gender differences (f:3).

The student coded 7K5Ö explained her opinions about not including controversial issues in the classroom due to the likelihood of conflict in the classroom as: "Because when my opinion and someone else's opinion are different, there are many fights and conflicts in the classroom. This happens verbally rather than physically. It happens especially in matters related to politics, political parties, or government. Therefore, these issues should not be included in order not to cause a fight." while the student coded 6K6Ö expressed her opinions about not including controversial issues due to the age barrier and the likelihood of affecting students psychologically as: "Before including a controversial issue in the course, our psychological readiness should also be considered. We are too young for some issues; it may cause some psychological problems for us. In other words, issues that affect us negatively and cause us to feel mentally depressed should not be included."

\section{Conclusion, Discussion, and Recommendations}

The purpose of this research was to determine middle school students' opinions about including controversial issues in social studies course. According to the quantitative results of the research, it was found that the controversial issue that the students want to be included in the social studies course the most is human rights, while the issue that they do not want to be included in the social studies course is terrorism. This finding is supported by the study of Çopur and Demirel (2016). Similarly, in a study conducted by Öztürk and Kuş (2019), it was found that human rights is among the most frequent issues covered by social studies teachers. This situation can be interpreted as those teachers and students have a common opinion on including human rights in social studies lessons.

According to another result, it was found that male students had a more positive view of including some controversial issues (military service and fanaticism) than female students. This result can be interpreted as gender differences have an impact on opinions on controversial issues. This result is consistent with the results of Ersoy's (2010) study.

Another result in this dimension was that the students' opinions on the inclusion of controversial issues in the course differed in terms of their reading habits. There was a significant difference in favor of the students who read books about including some controversial issues such as multiculturalism, animal rights, human rights, privatization, and the electoral system. This situation may be related to the formal operational period that the students are in because it is the period when individuals develop high-level mental skills and seek solutions to social problems (Küçükkaragöz, 2007).

Another result of the research was that students' opinions differed in terms of grade levels and the city they live in. There was a significant difference in favor of 7 graders in terms of freedom of the press and terrorism. In their study, Uygun and Arslan (2020) determined that human rights were the topic that 7 graders wanted to be included in the social studies course the most, but terrorism was the topic that most of the students did not want to be included.

According to the qualitative results of the research, it was observed that the participants defined the concept of the controversial issue as the topics that were approached differently, and the topics discussed. When the literature was reviewed, it was also observed that 
controversial issues were defined as issues that are thought differently or discussed (Bailey, 1975; Dearden, 1981; Stradling, 1984; Berg, Graeffe \& Holden, 2003; McCully, 2006, Yazic1 \& Seçgin, 2010; Y1lmaz, 2012).

According to another result, the course in which controversial topics covered the most place was the social studies course, followed by the science course. The reason for this situation may be that the content of the social studies course is structured differently from other courses because social studies has emerged with the integration of different disciplines within the social sciences (Bilgili, 2013, p. 4). Interdisciplinary knowledge is also required to address controversial issues (QCA, 1998). It can be stated that these two conditions affect this result. Moreover, a controversial issue may be related to both natural and social sciences (Ersoy, 2013; Kuş, 2015). However, controversial issues often arise in social studies class (Clabough, Philpott, McConkey \& Turner, 2011).

Another qualitative result was that the controversial topics that were wanted to be included in the course were mostly violence and rights related to the social sphere. It was observed that the opinions about violence were mostly concentrated on violence against women. Violence is a problem that has different causes in the world and our country, and the solution has not been found yet. The most common type is the one against women and children by men (Akkaş \& Uyanı, 2016). On the contrary, in their study, Uygun and Arslan (2020) determined that 7 graders did not want to discuss the issue of violence in the classroom. The reason why the participants wanted this subject to be included maybe that violence against women was heavily covered in the media at the time the research was conducted, and they might have wanted to raise awareness about it.

It has been concluded that the students' reasons to include controversial topics in the social studies course were to learn about controversial issues, to become conscious about these issues, to use the freedom of thought, and to learn values through these issues. This result can be interpreted as students can learn values, think at a higher level, and have different perspectives thanks to controversial issues (Soley, 1996; Camicia \& Dobson, 2010).

In this dimension, it was concluded that the issues that the students did not want to be included in the social studies course were the topics about the state (politics, political parties, government). This may be because students are afraid of their teachers, parents, or school administration. Similarly, teachers avoid covering these issues for the same reasons (Camicia, 2008; Hess, 2005; Journell, 2011).

Another result in this dimension was that students' opinions on issues related to state security (military service and terrorism) differed. According to some of the students, issues related to state security should be included in the course, while according to some of them, they should not. However, in the quantitative dimension, it was determined that terrorism was the subject that the students did not want to be included in the course. Regarding the military system, there was a significant difference in favor of male students. According to Hess (2001), having knowledge about and being interested in the topic are effective in including that topic in the course. Another result was that the students did not want some controversial topics to be included in the lesson because they create conflict in the classroom, are not age-appropriate, cause future anxiety, psychological effects, and gender difference.

The following recommendations were made based on the results of this research: 
- Controversial issues that students want to be included in the course should be added if they are not present in the curriculum,

- Creating a classroom climate where students can bring more controversial issues to the classroom,

- Encouraging teachers to bring controversial issues more into the classroom environment,

- Reducing conflicts in the classroom while teaching controversial topics,

- It is recommended that this research should be carried out more comprehensively with students studying in different regions of Turkey.

\section{Acknowledgment}

This study was presented at the 8th International Eurasian Educational Research Congress.

\section{References}

Akkaş, İ., \& Uyanık, Z. (2016). Violence against women. Nevşehir Hacı Bektaş Veli University Journal of ISS. 6(1), 32-42.

Bailey, C. (1975). Neutrality and rationality in teaching. D. Bridges \& P. Scrimshaw (Eds), Values and authority in schools. London: Hodder \& Stoughton.

Barton, K., \& McCully, A. (2007). Teaching controversial issues... where controversial issues really matter. Teaching History, 127, 13.

Berg, W., Graeffe, L., \& Holden, C. (2003). Teaching controversial issues: A European perspective. Children's Identity and Citizenship in Europe, CiCe.

Bilgili, A. S. (2013). Geçmişten günümüze sosyal bilimler ve sosyal bilgiler [Social sciences and social studies from past to present]. (Ed. A. S. Bilgili). Sosyal bilgilerin temelleri [In fundamentals of social studies] (pp. 2-35). Ankara: Pegem Publishing.

Büyüköztürk, Ş., Cakmak, E. K., Akgün, O. E., Karadeniz, S., \& Demirel, F. (2014). Bilimsel araştırma yöntemleri [Scientific research methods] Ankara: Pegem Publishing.

Camicia, S. P. (2008). Deciding what is a controversial issue: A case study of social studies curriculum controversy. Theory \& Research in Social Education, 36(4), 298-316.

Camicia, S. P., \& Dobson, D. (2010). Learning how to respond to current events: Partner journals between US preservice teachers and children. Teaching and Teacher Education, 26(3), 576-582.

Chikoko, V., Gilmour, J. D., Harber, C., \& Serf, J. (2011). Teaching controversial issues and teacher education in England and South Africa. Journal of Education for Teaching, 37(1), 5-19.

Clabough, J., Philpott, S., McConkey, L., \& Turner, T.N. (2011). Teachers'struggles with controversial issues: Facing the demon. National Social Science Journal, 38(2), 1-5.

Copur, A., \& Demirel, M. (2016). Turkish social studies teachers' thoughts about the teaching of controversial issues. JSSE-Journal of Social Science Education, 15(2), 80-95.

Creswell, J. W. (2012). Educational research: Planning, conducting, and evaluating quantitative and qualitative research. Boston, MA: Pearson Education.

Dearden, R. F. (1981). Controversial issues and the curriculum. Journal of Curriculum Studies, 13(1), 37-44.

Ersoy, A. F. (2010). Social studies teacher candidates' views on the controversial issues incorporated into their courses in Turkey. Teaching and Teacher Education, 26(2), 323-334. 
Ersoy, A. F. (2013). Factors affecting the participation of social studies teacher candidates in discussions on controversial issues. Journal of Social Studies Education Research, 4(1), 24-57.

George, D., \& Mallery, P. (2010). SPSS for Windows step by step. A. Simple study guide and reference. GEN, Boston, MA: Pearson Education, Inc.

Günal, H., \& Kaya. R., (2016). Problems and drawbacks that history teachers experience while teaching controversial and sensitive issues (Erzurum sample). Turkish History Education Journal, 5(1), 44-73.

Harwood, A. M., \& Hahn, C. L. (1990). Controversial issues in the classroom. Bloomington, IN: ERIC Clearinghouse for Social Studies/Social Science Education.

Hess, D. (2001). Teaching students to discuss controversial public issues. ERIC Clearinghouse for Social Studies/Social Science Education, Indiana University.

Hess, D. (2005). How do teachers' political views influence teaching about controversial issues. Social Education, 69(1), 47-48.

Hess, D. E. (2004). Controversies about controversial issues in democratic education. PS: Political Science \& Politics, 37(2), 257-261.

Hess, D., \& Posselt, J. (2002). How High School Students Experience and Learn from the Discussion of Controversial Public Issues. Journal of curriculum and supervision, 17(4), 283-314.

Küçükkaragöz, H. (2007). Bilişsel gelişim ve dil gelişimi [Cognitive development and language development]. (Ed. B. Yeşilyaprak) Ĕ̆itim psikolojisi [In education psychology] (pp. 81-115). Ankara: Pegem Publishing.

Kuş, Z. (2015). Science and social studies teachers' beliefs and practices about teaching controversial issues: Certain comparisons. JSSE-Journal of Social Science Education, 84-97.

Lockwood, A. L. (1995). Controversial issues: The teacher's crucial role. Social Education, 60(1), 28-31.

McCully, A. (2006). Practitioner perceptions of their role in facilitating the handling of controversial issues in contested societies: A Northern Irish experience. Educational review, 58(1), 51-65.

Miles, M. B., \& Huberman, A. M. (1994). Qualitative data analysis: An expanded sourcebook, Thousand Oaks, CA: Sage.

Miller, H. L., \& Flores, D. (2011). Teaching controversial issues, liberally. Effective College and University Teaching: Strategies and Tactics for the New Professoriate, 155.

Ministry of National Education, (2018). Sosyal bilgiler dersi öğretim programı. [Social studies course curriculum] Retrieved from https://mufredat.meb.gov.tr on 13.04.2021.

Oulton, C., Day, V., Dillon, J., \& Grace, M. (2004). Controversial issues-teachers' attitudes and practices in the context of citizenship education. Oxford review of education, 30(4), 489-507.

Oxfam GB. (2006). Global Citizenship Guides, Teaching Controversial Issues. Retrieved from http://www.worldwiseschools.ie/wp-content/uploads/2018/05/Oxfam-TeachingControversial-Issues.pdf on 15.07.2021

Ozturk, D., \& Kus, Z. (2019). Social studies teachers' opinions and practices regarding teaching controversial issues. Australian Journal of Teacher Education (Online), 44(8), 15-37.

Qualifications and Curriculum Authority. [QCA] (1998). Education for citizenship and the teaching of democracy in schools Final report of the Advisory Group on Citizenship. London: Qualifications and Curriculum Authority.

Soley, M. (1996). If it's controversial, why teach it? Social Education, 60(1), 9-14. 
Stradling, R. (1984). The teaching of controversial issues: an evaluation. Educational Review, 36(2), 121-129.

Tuncer, R, H. (2018). Examining social studies teacher candidates' opinions about teaching controversial subjects. Firat University Institute of Educational Science Department of Turkish and Social Sciences Education Department of Social Sciences Education Elazı̆g.

Uygun, K., \& Arslan, I. E. (2020). Students' opinions about teaching of the controversial topics in the social studies classes. International Journal of Evaluation and Research in Education, 9(2), 335-344.

Washington, E. Y., \& Humphries, E. K. (2011). A social studies teacher's sense making of controversial issues discussions of race in a predominantly white, rural high school classroom. Theory \& Research in Social Education, 39(1), 92-114.

Yazıc1, S., \& Seçgin, F. (2010). A study on teaching controversial issues. Journal of International Social Research, 3(12).

Yıldırım, A., \& Simsek, H. (2018). Sosyal bilimlerde nitel araştırma yöntemleri. [Qualitative research methods in the social sciences] Ankara: Seçkin Publishing.

Y1lmaz, K. (2012). Investigation into controversial issues and taboo topics: Social studies teachers' perspectives. Mustafa Kemal University Journal of Social Sciences Institute 9(18), 201-225. 